NBER WORKING PAPER SERIES

\title{
BETTING ON DEATH AND CAPITAL MARKETS IN RETIREMENT: A SHORTFALL RISK ANALYSIS OF LIFE ANNUITIES VERSUS PHASED WITHDRAWAL PLANS
}

\author{
Ivica Dus \\ Raimond Maurer \\ Olivia S. Mitchell \\ Working Paper 11271 \\ http://www.nber.org/papers/w11271 \\ NATIONAL BUREAU OF ECONOMIC RESEARCH \\ 1050 Massachusetts Avenue \\ Cambridge, MA 02138 \\ April 2005
}

This research was conducted with support from the Social Security Administration via the Michigan Retirement Research Center at the University of Michigan, under subcontract to the University of Pennsylvania. Additional support was provided by the Center for Financial Studies of the University of Frankfurt and the Pension Research Council of the Wharton School at the University of Pennsylvania. Data collection was facilitated by the German Investment and Asset Management Association (BVI). Research for the paper was undertaken while the second author was a Metzler Visiting Professor at the Department of Insurance and Risk Management at the Wharton School. We are grateful for comments provided by Chris Robinson, Neil Doherty, Alex Muermann, Stephen Shore, and Kent Smetters. Opinions and errors are solely those of the authors and not of the institutions with whom the authors are affiliated. This is part of the NBER Program on the Economics of Aging. The views expressed herein are those of the author(s) and do not necessarily reflect the views of the National Bureau of Economic Research.

(C2005 by Ivica Dus, Raimond Maurer, and Olivia S. Mitchell. All rights reserved. Short sections of text, not to exceed two paragraphs, may be quoted without explicit permission provided that full credit, including (C) notice, is given to the source. 
Betting on Death and Capital Markets in Retirement: A Shortfall Risk Analysis of Life Annuities versus Phased Withdrawal Plans

Ivica Dus, Raimond Maurer, and Olivia S. Mitchell

NBER Working Paper No. 11271

April 2005

JEL No. G22, G23, J26, J32, H55

\begin{abstract}
$\underline{\text { ABSTRACT }}$
Retirees must draw down their accumulated assets in an orderly fashion, so as not to exhaust their funds too soon. We compare alternative phased withdrawal strategies to a life annuity benchmark using German data; one particular phased withdrawal rule seems attractive, as it offers relatively low expected shortfall risk, good expected payouts for the retiree during his life, and some bequest potential; results are similar for the US case. Delayed annuitization may also appeal, as it offers higher expected benefits with lower expected shortfalls. Requiring unisex mortality tables in annuity pric-ing raises women's risks under a phased withdrawal program.

Ivica Dus

University of Frankfurt

dus@wiwi.uni-frankfurt.de

Raimond Maurer

University of Frankfurt

rmaurer@wiwi.uni-frankfurt.de

Olivia S. Mitchell

Department of Insurance \& Risk Management

University of Pennsylvania, Wharton School

3620 Locust Walk, St 3000 SH-CH

Philadelphia, PA 19104-6302

and NBER

mitchelo@wharton.upenn.edu
\end{abstract}




\title{
Betting on Death and Capital Markets in Retirement: A Shortfall Risk Analysis of Life Annuities versus Phased Withdrawal Plans
}

\author{
Ivica Dus, Raimond Maurer, and Olivia S. Mitchell
}

Economists often advise retirees seeking to spread their assets over their retirement period to purchase a life annuity, which is a financial contract between an insured person and an insurer "that pays out a periodic amount for as long as the annuitant is alive, in exchange for an initial premium"

(Brown et al., 2001). Annuity payments may be fixed in nominal terms (fixed annuity); they can rise at a pre-specified fixed nominal escalation rate (graded annuity); or they can be indexed to inflation (real annuity). Alternatively, they may reflect the return of a specific asset portfolio which backs the (variable) annuity, or they can depend on the insurance company's experience with mortality, investment returns, and expenses (participating annuity). As Mitchell et al. (1999) note, the essential attraction of a life annuity is that the individual is protected against the risk of outliving his own assets, given uncertainty about his remaining lifetime, by pooling longevity risk across a group of annuity purchasers. Yaari (1965) shows that risk-averse retirees without a bequest motive facing annuity markets that charge actuarially fair premiums, should annuitize 100 percent of their wealth.

Though life annuities provide invaluable longevity insurance, they also have some disadvantages. Most obviously, the purchaser faces loss of liquidity and control over his assets, because the lump sum premium cannot be recovered after purchase of the annuity, irrespective of special needs (e.g. to cover unexpected and uninsured medical costs; c.f. Brugiavini 1993). Also, if the annuity payments are contingent on the individual's survival, there is no chance of leaving a bequest for one's heirs. Other explanations for why people may be reluctant to buy annuities are the high administrative costs levied by insurance companies (Mitchell et al., 1999), the ability to pool longevity risk within families (Brown and Poterba, 2000; Kotlikoff and Spivak, 1981), and the presence of 
other annuitized resources from Social Security or employer-sponsored defined benefits plans (Munnell et al., 2002).

As an alternative to buying a life annuity, one might "self-annuitize" following a phased withdrawal approach. Here the retiree allocates his wealth endowment across various asset categories (e.g. equity, bonds, cash) typically included in a family of mutual funds where the assets will earn uncertain rates of return. A certain amount of the invested funds can then be withdrawn periodically for consumption purposes. An advantage of the phased withdrawal strategy, as compared to a life annuity, is that it offers greater liquidity, the possibility of greater consumption while alive, and the possibility of bequeathing some of the assets in the event of early death. On the other hand, relying on a steady asset drawdown without any insurance provides no pooling of longevity risk, so the retiree could outlive his assets before his uncertain date of death. Another withdrawal rule, for example, consuming a specified fraction of the remaining fund wealth each period, avoids the risk of outliving one's total assets, as long as the benefit-to-wealth ratio is lower than one. Yet stochastic investment returns will mean that pension assets change over time, and the periodically withdrawn amount could be substantially lower or higher than the benefit payable under a life annuity.

Such phased withdrawal approaches are becoming popular in many countries, prompted by a round of pension reforms in Europe and America. For example, in Germany, recently-introduced "Riester plans" offer a tax inducement for voluntary saving in individual pension accounts (IPA) during the worklife, underscoring the government's interest in boosting asset accumulation for the aging population (Börsch-Supan et al., 2003). At retirement, thirty percent of the accumulated assets in the IPA may be withdrawn as a lump-sum distribution; the remainder must be taken as a life annuity (offered by a commercial insurance company) or paid out according to a phased withdrawal plan (typically offered by mutual fund and/or bank providers) of which part reverts to an annuity as of age 85 . In the UK, personal pensions are now the norm, and here too, a portion of the accumu- 
lated asset must be annuitized by age 75 . In Canada, the retiree at age 69 must either buy an annuity with his tax-sheltered saving or create a discretionary managed withdrawal plan (Milevsky and Robinson, 2000). In the US, no compulsory annuitization is required for 401(k) plans; rather, most retirees roll over their pension assets into an Individual Retirement Account and manage the funds themselves in old age. Together, these trends signal a growing interest in helping retirees manage the asset decumulation process.

To compare alternative retirement asset decumulation strategies quantitatively, we require a formal risk/return framework for decision-making under uncertainty. One approach taken by financial economists is to maximize the expected discounted value of a (time separable) utility function for uncertain future benefits and (if necessary) for a bequest. For example, Blake et al. (2003) evaluate different withdrawals plans assuming that mandatory annuitization is required at age 75 , using a constant relative risk aversion utility framework. Milevsky and Young (2003) use a similar objective function to determine the option value of deferring annuitization. A shortcoming of such an approach, however, particularly in the world of financial retirement planning, is that decisionmakers often lack an explicit measure of retirees' risk preferences (Pye 2000). For this reason, an alternative approach using risk-value (or risk-return) models are appealing, in that they use explicit measures of risk and value along with a function reflecting the tradeoff between these two. To the extent that individuals prefer more return to less, and less risk to more, we can derive a partial ordering of opportunities within a risk-return dominance context, even if the exact utility weights for risk and return are unknown. Depending on which risk metric is selected and how we formulate the tradeoff between risk and return, a risk-value model can be consistent with the expected utility approach of choice (Sarin and Weber 1993).

In what follows, we therefore take a risk-value approach. Here the "return" is the expected level of benefits as well as the expected possibility of bequest, and the "risk" is the possibility of not 
reaching a benchmark or desired level of consumption. Previous studies taking this tack focus on the probability of consumption shortfall as the operative risk measure (Ho et.al 1994, Bengen 1994, 1996 Milevsky et al. 1997, Milevsky and Robinson 2000, Milevsky 1998, 2001, Ameriks et al. 2001, Pye 2001, Hughen et al. 2002, or Albrecht and Maurer 2002). Assuming that the retiree consumes a fixed amount at specific points in time from a self-managed pension account, those studies calculate the probability of running out of money before an uncertain date of death using alternative assumption about the asset allocation, the initial consumption-to-wealth ratio, and the optimal waiting time before switching the retirement wealth into an annuity. Our work extends this literature in several directions. First, we examine the risk and return profiles of several variable self-annuitization strategies that provide payments according to a predetermined benefit-to-wealth ratio. Second, we address a major shortcoming of the shortfall-probability risk measure, namely that it ignores the size of the possible loss that may be experienced. In practice, of course, both theoretical and empirical arguments suggest that investors take both the probability and the amount of a possible shortfall into consideration. Our contribution is to go beyond prior work by looking not only at the probability of a consumption shortfall, but also consider the size of the shortfall when it occurs. Third, we examine how the results change if a mandatory annuitization rule were imposed akin to those in the recent German and UK pension reforms. Fourth, we evaluate the impact of allowing the annuitization date to be endogenous, along with the asset allocation decision. We illustrate how the risk of a consumption shortfall and return profiles of fixed and variable phased withdrawal strategies compare to the life annuity, and indicate what dominant strategies might be.

In the remainder of this paper, we describe several withdrawal strategies and illustrate their implications assuming capital and insurance market conditions relevant to the German marketplace. We adopt these so as to be informative about alternative payout options that might be contemplated under the German Riester plans when they reach maturity. Most results focus on an age-65 male 
retiree, but we also provide findings for other ages and for women. Results are first given using a fixed asset allocation pattern, and subsequently, assets are permitted to be allocated optimally. A final section summarizes and concludes.

\section{The Case of Phased Withdrawal}

We assume that the retiree is endowed with an initial level wealth $V_{0}$ that he can use to buy a single-premium immediate life annuity paying constant annual real benefits $B$ at the beginning of each year for life, with no bequest. We denote this as the benchmark annuity, and refer to Appendix A regarding the pricing of such an insurance product using assumptions about mortality, loadings, and interest rates. If the retiree does not annuitize his wealth, he must allocate his retirement money across various financial assets such as equities and bonds (represented here as mutual funds); thereafter, he can withdraw a certain amount at the beginning of each year for consumption purposes. Throughout, we assume that payouts are taxed as ordinary income; therefore taxes will not change the desirability of voluntary annuitization or systematic withdrawal from a self-managed retirement account. ${ }^{1}$

\section{Withdrawal Plans with Fixed Benefits}

Under a fixed benefit rule, at the beginning of each year the retiree will sell as many fund units as required to reach the same yearly benefits paid by the life annuity, either until he dies or the retirement assets are exhausted. Formally, the benefits $B_{t}$ at the beginning of each year are given by:

$$
B_{t}=\min \left(B, V_{t}\right) \text {, }
$$

where $V_{t}$ is the value of the retirement accounts assets wealth at the beginning of year $t(t=0,1, \ldots)$ just before the withdrawal $B_{t}$ for that year is made. The retiree faces an intertemporal budget con-

\footnotetext{
${ }^{1}$ This is accurate for the German context; for more on annuity tax treatment in the US see Brown et al. (2001). Hugen et al (2002) studies the cash-flows of various withdrawal rates (as a percentage of initial portfolio value) within an ex post context using historical returns data on common stocks and bonds before and after taxes.
} 
straint such that wealth next period $V_{t+1}$ equals wealth today $V_{t}$, less what is subtracted for benefit payments $B_{t}$, times the (inflation adjusted) portfolio return $R_{t+1}$ over the period, or zero if the fund is exhausted:

$$
V_{t+1}=\left(V_{t}-B_{t}\right) \cdot\left(1+R_{t+1}\right)=\left\{\begin{array}{cc}
\left(V_{t}-B\right)\left(1+R_{t+1}\right) & V_{t}>B \\
0 & V_{t} \leq B
\end{array} .\right.
$$

Note that the benefit paid $B_{t}$ depends on the value of the retirement assets used to finance withdrawals, $V_{t}$. If these assets are risky, benefit payouts are exposed to uncertain capital market returns. The idea of the fixed benefit rule is to replicate the payout from a life annuity (self-annuitization) as long as the funds permit, while at the same time offering liquidity and some bequest potential in the event of an early death. Nevertheless, the risk of such a self annuitization strategy is that adverse capital markets linked to longevity outcomes might produce a situation where $V_{t}$ hits zero and therefore $B_{t}=B_{t+1}=\ldots=0$, while the retiree is still alive.

\section{Phased Withdrawal Rules with Variable Benefits}

Under a variable phased withdrawal plan, the retiree receives an ex ante fixed fraction of the retirement assets remaining each period (as in Merton 1971). Due to the stochastic nature of capital markets, the value of the retiree's fund is exposed to positive as well as negative fluctuations. Consequently, the level of benefit payments under a variable withdrawal plan also fluctuates in tandem with the account value.

The path of benefits payable under a variable phased withdrawal rule can be formalized as follows. Let $V_{t}$ be the value of the retirement assets at the beginning of period $t(t=0,1, \ldots)$ before the withdrawal $B_{t}$ for that year is made. At the beginning of period $t$, an ex ante specified fraction $\omega_{t}$ $\left(0<\omega_{t} \leq 1\right)$ is withdrawn from current wealth; hence the retiree receives a payment according to:

$$
B_{t}=\omega_{t} \cdot V_{t}
$$


Further let $R_{t+1}$ denote the return of the funds over the period. Then, the intertemporal budget constraint of the retirement account is given by:

$$
V_{t+1}=\left(V_{t}-B_{t}\right) \cdot\left(1+R_{t+1}\right)=\left(1-\omega_{t}\right) \cdot V_{t} \cdot\left(1+R_{t+1}\right)
$$

Note that if the assets of the pension account are invested in risky assets, both the pension benefits $B_{t}$ as well as the bequest potential $V_{t}$ are random variables. In what follows, we focus attention on three specific withdrawal rules that generate variable benefits: the fixed percentage rule, the $1 / \mathrm{T}$ rule, and the $1 / \mathrm{E}(\mathrm{T})$ rule. Each is discussed in turn.

“Fixed Percentage” Withdrawal Rule: Here a constant fraction is withdrawn each period from the remaining fund wealth; that is, the benefit-wealth ratio is fixed over time:

$$
\frac{B_{t}}{V_{t}}=\omega_{t}=\omega
$$

This withdrawal rule has the advantage of simplicity, requiring no information regarding the maximum possible duration of the payout phase or the retiree's demographic characteristics.

"1/T Rule" Withdrawal Rule: The idea behind this rule is to set the withdrawal fraction according to the maximum possible duration of the plan, denoted by $T$. One way is to set $T$ equal to the oldest age assumed in a mortality table; another is to fix it at the retiree's life expectancy as of his retirement date (Brown et al., 1999). In the first case, the maximum number of payments $T$ is given by the limiting age $l$ of the mortality table minus the current age of the retiree $x$ plus one $(T-1-x+1)$.

The retiree gets a fraction of $1 / T$ of his initial pension account as the first payment, the second payment is worth $1 /(T-1)$ of the remaining assets, and so forth until the retiree either passes away or reaches the plan's limiting age $l$. Formally, the benefit-wealth ratio at the beginning of year $t(t=0,1, \ldots T-1)$ of this retirement plan is given according to:

$$
\frac{B_{t}}{V_{t}}=\omega_{t}=\frac{1}{T-t} .
$$


In contrast to the fixed percentage rule discussed above, the withdrawal fraction is not constant, but rather rises with age.

“1/E[T(x)]" Withdrawal Rule: This rule, which we will call the $1 / \mathrm{E}(\mathrm{T})$ rule for short, takes into account the retiree's remaining life expectancy in a dynamic way. Now, the withdrawal fraction is no longer determined by the maximum length of the plan, but instead it is a function of the retiree's remaining life expectancy. Let ${ }_{t} p_{x}$ represents the conditional probability that an $x$-year old man will attain age $\mathrm{x}+t$, the complete expectation of life is calculated as $\mathrm{E}[T(x+t)]=\sum_{t=0}^{l-x}{ }_{t} p_{x}$ where $l$ is the maximum age according to a mortality table. Then, for an at retirement x-year old man, the benefitto-wealth ratio in period $t$ after retirement, conditional on the fact that he is still alive, is given as:

$$
\frac{B_{t}}{V_{t}}=\omega_{t}=\frac{1}{\mathrm{E}[T(x+t)]} .
$$

The shorter his expected remaining lifetime, the higher the fraction he will withdrawal from his pension account. The $1 / \mathrm{E}(\mathrm{T})$ withdrawal rule is used in the US during the decumulation phase of 401(k) plans, where the tax authority seeks to ensure that retirees consume their tax-qualified pension accounts instead of leaving them as bequests for their heirs (see Munnell et al., 2002).

\section{Risk and Reward Analysis of Phased Withdrawal Plans Conditional on Survival}

\section{Research Design}

To compare the risk and value characteristics of the four phased withdrawal rules of interest, it is useful to begin with an assessment of expected payouts conditional on retiree survival. For the moment, therefore, we focus only on the risk resulting from capital markets and suppress mortality. To do so, we assume a 65-year old male retiree who seeks to compare benefits under the four phased withdrawal plans given an initial asset balance. His retirement assets are rebalanced annually to maintain an asset pool split evenly between stocks and bonds, consistent with recommenda- 
tions by financial advisors. ${ }^{2}$ The analysis to follow uses assumptions drawn from the German capital and annuity market environment; later, we offer some comparisons with US assumptions. The annuitant mortality table is provided by the German Society of Actuaries and used to calculate survival probabilities and expected lifetime (in the $1 / \mathrm{E}(\mathrm{T})$ case). Since this table ends at age 110, we set $l=110$ for the $1 / T$ rule. For the fixed percentage withdrawal rule, we select $\omega=5.82 \%$, since this benefit-to-wealth ratio produces an initial payout equal to the life annuity in the first year of the plan. In the case of the fixed benefit rule, we assume that the initial withdrawal continues until the retiree dies or the account is exhausted.

We compare the risk and return patterns that emerge under these alternative phased withdrawal patterns to those from a fixed real annuity providing lifelong constant payouts. When focusing on risks and benefits, the computations either assume that the retiree is alive, or conversely, we evaluate the bequest potential if the retiree is assumed to pass away at a specific age. To do so, we specify an exogenous structure on the ex-ante probability distribution governing the financial uncertainty of future returns and estimate the parameters of such a model from independent (e.g. yearly) historical observations of real returns. With such a model in place, it is possible to look into the future and compute the expected benefit payments and different shortfall-risk measures of the four withdrawal plans in which we are interested. Implementing it relies on the assumption that the stochastic specification of the asset values in the retirement account follows a geometric random walk with drift, a standard assumption in financial economics. This implies that the yearly log-returns are serially independent and identically normally distributed with given mean and covariance. We

\footnotetext{
${ }^{2}$ Feldstein et al. (2001) and Ibbotson (2003) assume that retirees hold their non-annuitized assets in a $60 \%$ stock, $40 \%$ bond portfolio. Here, for illustrative purposes, we use a more conservative 50-50 split, consistent with the position recommended by the President's Commission to Strengthen Social Security (see Cogan and Mitchell (2003)). Some financial advisers propose that investors hold equities equal to 100 minus their age; see Canner et al. (1997) or Vora and McGinnes (2000). The number 100 can be justified as it is the maximum age used in most population mortality tables, but annuitant mortality tables often have a maximum age 10-15 years higher.
} 
also use German historical time series over the period 1967-2004 for the German Equity Index (DAX) and the German Bond Index (REXP) as proxies for stock and bond investments. The DAX represents an index portfolio of German blue-chip stocks, and the REXP represents a portfolio of German government bonds. Each of these indices is adjusted for capital gains as well as dividends and coupon payments (on a pre-tax basis). To account for potential administrative costs, we subtract the equivalent of $0.5 \%$ p.a. from the yearly portfolio return. Subsequently, asset returns are adjusted for inflation by using the German Consumer Price Index.

These yearly data produce estimates for the real log average rate of return for stocks of 6.18 percent and 3.96 percent for bonds, respectively. The corresponding volatilities are 25.00 percent for stocks and 5.07 percent for bonds, and the correlation-coefficient is 0.22 . Since we assume normally distributed $\log$ returns, i.e. $I_{t}=\ln \left(1+R_{t}\right) \sim \mathrm{N}(\mu, \sigma)$, these parameters imply a real $\log$ mean rate of return on the fifty-fifty stock-bond portfolio of $\mu=5.81$ percent with a standard deviation of $\sigma=13.28$ percent. Note that this produces an expected gross rate of return of $\mathrm{E}\left(1+R_{t}\right)=\mathrm{E}\left[\exp \left(I_{t}\right)\right]$ $=\exp \left[0.0581+0.5^{*} 0.1328^{2}\right]=1.0692$. Assuming ${ }^{3}$ that the normality property also holds for the $\log$ portfolio returns, it is straightforward to develop an analytical closed form solution for the probability distribution of future benefits of the different variable phased withdrawal rules (see Appendix B for details). However, because the value of the retirement accounts value might hit zero, the intertemporal budget constraint in equation (2) for the fixed benefit rule is not (log)linear, and future benefits are path-dependent. Hence, for the fixed benefits withdrawal plan, the probability distribution of future benefits is unknown. As a result, estimates for the different risk and return measure use Monte-Carlo simulation to generate a large number (i.e. 100,000) of paths for the evolution of the withdrawal plan.

\footnotetext{
${ }^{3}$ This assumption is widely used in the strategic asset allocation literature (e.g. Feldstein et al. 2001 or Campbell and Viceira 2002) and it can be justified by a Taylor approximation of the nonlinear function relating log-individual-asset returns to $\log$ portfolio returns. For details see Campbell and Viceira (2002), p. 28-29 and Campbell et al. (2001).
} 


\section{$2 \quad$ Analysis of Expected Benefits}

Figure 1 depicts the Expected Benefits profiles conditional on survival under all four phased withdrawal rules; in each case payouts are compared to the annuity profile. Focusing on the fixed benefit rule, we see that in the first year, mean benefits are (by construction) equal to the annuity payout. Thereafter, however, expected payments from the plan are decreasing, reflecting the risk of running out of money. The fixed fraction rule also starts with a benefit equal to the life annuity payout, and after that, mean benefits slightly rise as the retiree ages. This is due to the fact that the pension account's expected gross rate of return is $6.92 \%$ p.a., which exceeds the constant benefit-towealth-ratio of $5.82 \%$ p.a. (i.e. $1.0692 *(1-0.0582)=1.007>1)$.

\section{Figure 1 here}

By contrast, the $1 /$ T rule pays a much lower expected benefit up to the age of 80 , but thereafter, the expected benefit rises extremely quickly and to very high levels. This can be explained by the low withdrawal fractions under this rule, during the first part of the retirement plan. Up to age 95, the benefit-to-wealth ratio is lower than the expected rate of return; consequently, the expected value of the pension assets grows over time. "Reserves" built up in earlier ages can be used to increase the expected benefits in later years. The $1 / \mathrm{E}(\mathrm{T})$ rule starts at a level of about $85 \%$ of the annuity payment and increases to $100 \%$ when the retiree attains age 70 . This payout approach reaches its maximum expected payment of about $150 \%$ at age of 83 . After that point, expected payments monotonically decrease, reaching the life annuity benefit level at age 91. For ages older than 100, the $1 / \mathrm{E}(\mathrm{T})$ rule would expose the retiree to very low benefits, asymptotically approaching zero. Only for the first six years of the retirement plan will the benefit-to-wealth ratio be lower than the expected return earned on pension assets. If the retiree survives until age 71 , his expected lifetime is about 15 years, resulting in a withdrawal fraction of $6.66 \%$ which is about the same as the expected rate of return. Beyond that age, the withdrawal fraction grows ever larger than the expected asset 
returns backing benefit payments. For some time (i.e. up to age 83), the increasing withdrawal fractions produce increasing expected benefits. But because less and less wealth is left in the fund, at some point (here age 83) the expected benefit amounts decrease although the withdrawal fraction increases.

\section{Shortfall Risk Analysis}

In general, shortfall risk is associated with the possibility of "something bad happening", in other words, falling below a required target return. Returns below the target (losses) are considered to be undesirable or risky, while returns above the target (gains) are desirable or non-risky. In this sense, shortfall-risk-measures are called "relative" or "pure" measures of risk. ${ }^{4}$ To analyze this risk in the case of our phased withdrawal strategies, we employ several different shortfall risk measures.

Shortfall Probability: We begin with the shortfall probability, defined as:

$$
\mathrm{SP}\left(B_{t}\right)=\mathrm{P}\left(B_{t}<z\right)
$$

This measures the probability that the periodic withdrawal $B_{t}$ is smaller than a chosen benchmark $z$, which is here the payment provided by the life annuity.

Figure 2 depicts the SP for the fixed benefit rule, the fixed fraction rule, the 1/T approach, and the $1 / \mathrm{E}(\mathrm{T})$ rule, compared to the annuity benefit. In the first year, all the strategies except the fixed benefit program face a high probability of shortfall; the only reason the fixed benefit approach does not is that it is set, by construction, to pay the initial annuity value as long as the funds are not exhausted. Accordingly, the fixed benefit program offers a shortfall probability close to zero at the beginning of the retirement period, but this risk metric begins to rise over time, reaching about $20 \%$ around age 85 . By contrast, both the $1 / \mathrm{T}$ and $1 / \mathrm{E}(\mathrm{T})$ rules have high shortfall probabilities early in

\footnotetext{
4 The concept of shortfall risk was introduced in the area of finance by Roy (1952) and Kataoka (1963), and it was expanded and theoretically justified by Bawa (1978) and Fishburn (1977, 1982, 1984). It was widely applied to investment asset allocation by Leibowitz et al. (1996) and used by Leibowitz and Krasker (1988) and Maurer and Schlag (2003) among others to judge the long term risk of stocks and bonds. In addition Libby and Fishburn (1977); Kahneman and Tversky (1979); Laughhunn et al. (1980) and March and Shapira (1987) show that in empirical business decisionmaking, many individuals judge the risk of an alternative relative to a reference point.
} 
the retirement period. This is because a retiree investing his assets in a mutual fund hoping to generate the same payment offered by the life annuity must withdraw about $6.50 \%$ of the fund annually. But the withdrawal fractions under the $1 / \mathrm{T}$ and the $1 / \mathrm{E}(\mathrm{T})$ rules are smaller early in retirement, meaning that the wealth remaining grows quickly. Consequently the SP declines over time, though the withdrawal fraction is growing. The retiree that withdraws a fixed fraction each year faces a risk profile that is remarkably high for all ages. In early years, the probability of receiving a benefit below the benchmark life annuity is about $50 \%$, gradually increasing to about $54 \%$ at the end of the period.

Figure 2 here

Another interesting finding has to do with the gradient of the SP under the $1 / \mathrm{E}(\mathrm{T})$ rule. Early in the retirement period there is a fast decline in this risk, but if the retiree is still alive at age 83 , the SP begins to rise quickly due to the special construction of this spending rule. In contrast to the $1 / \mathrm{T}$ rule, expected payments at the beginning of the plan are already higher, meaning that few "reserves" are built up in the beginning of the plan. Also, the 65-year-old retiree has an expected remaining lifetime of 19 years, and his expected remaining lifetime decreases over time, especially after the age of 80 . The shorter is the remaining expected lifetime, the more wealth will be withdrawn in the $1 / \mathrm{E}(\mathrm{T})$ case. As the withdrawal fractions increase, less and less wealth is left in the fund; at some point, wealth remaining is insufficient to provide high enough payments, so the shortfall probability again rises.

Shortfall Measures That Incorporate Severity: As Bodie (2001: 308) notes, a major shortcoming of the popular SP risk metric is that it "completely ignores how large the potential shortfall might be." That is, the shortfall probability answers the question "how often" consumption falls short, but not "how bad" the loss is if it occurs, under each of the different withdrawal rules. A shortfall risk 
metric that considers both the probability and the average size of the shortfall when it occurs is the Shortfall Expectation (SE):

$$
\mathrm{SE}\left(B_{t}\right)=\mathrm{E}\left[\max \left(z-B_{t}, 0\right)\right]=\operatorname{MEL}\left(B_{t}\right) \cdot \operatorname{SP}\left(B_{t}\right)
$$

The SE is the sum of losses weighted by their probabilities, and hence it is a measure of the unconditional "average loss". As equation (9) shows, the SE is the product of the shortfall probability and the conditional expected shortfall given the occurrence of a shortfall. This measure is also known as the Mean Excess Loss and it is defined as $\operatorname{MEL}\left(B_{t}\right)=\mathrm{E}\left[z-B_{t} \mid B_{t}<z\right]$, i.e. the MEL answers the question of "how badly on average" the strategy performs (see Artzner et al. 1999).

In Figure 3 we plot the shortfall expectation results for the various withdrawal strategies of interest, namely the fixed benefit rule, the fixed fraction rule, the $1 / \mathrm{T}$ approach, and the $1 / \mathrm{E}(\mathrm{T})$ rule. The SEs can be compared for each tactic to the annuity benefit, all conditional on survival. Here we see that the fixed benefit rule has a very low shortfall expectation through about age 83 , whereas the $1 / \mathrm{T}$ rule is initially the riskiest with a $60 \% \mathrm{SE}$. It takes a very long time until the SE of the $1 / \mathrm{T}$ rule declines to a negligible level, older than age 90 for the case under study. The fixed fraction and the $1 / \mathrm{E}(\mathrm{T})$ rules both have SEs below $20 \%$ through at least age 80 , but the $1 / \mathrm{E}(\mathrm{T})$ rule again traces out what is perhaps unexpected behavior - after falling to low levels through about age 84, the risk begins to rise substantially 20 years after retirement, and it has the highest expected shortfall for the long-lived individual.

Figure 3 here

\section{Analysis of Expected Bequests}

The other aspect of these rules, of course, is that the retiree must in effect compare his own consumption with the potential value of any bequest going to his heirs should he die. Figure 5 illustrates the expected bequest under the various formulations, conditional on death. The pattern exhibiting most stability is the fixed fraction rule, but the other three are highly divergent. For example, 
the $1 / \mathrm{T}$ expected bequest follows an interesting path, rising during the early retirement period when withdrawals are small. About 35 years after retirement, however, the expected bequest begins to decline very quickly - a fact that is directly attributable to the construction of this plan. The older a retiree gets, the more he or she withdraws from his account: thus five years before the plan ends, the retiree withdraws $1 / 5$ (or $20 \%$ ) of the remaining wealth. If the retiree should, by chance, live beyond age 110 , this approach offers no continued payment or bequest potential. The $1 / \mathrm{E}(\mathrm{T})$ rule also offers only a very low bequest potential after reaching a limiting age. In contrast with the $1 /$ T tactic, however, the $1 / \mathrm{E}(\mathrm{T})$ plan offers lower expected inheritance at every age. Particularly if the retiree does not die until 20 years into retirement, the inheritance will decline dramatically.

Figure 4 here

\section{Risk-Minimizing Phased Withdrawal Strategies}

Thus far, our analysis has assumed that the retiree holds his pension assets in a fixed-weight portfolio comprised of 50\% stocks and 50\% bonds; accordingly the payouts in retirement take into account only capital market uncertainty, without permitting investment optimization around risk/reward tradeoffs. In this subsection, we extend the analysis by considering mortality risk and two additional phased withdrawal rules that permit the retiree to optimize the design of the withdrawal patterns. In the next subsection, we further vary the portfolio's investment weights to attain a risk-minimizing static asset allocation. The portfolio weights are therefore determined endogenously (excluding short-selling), following Albrecht and Maurer (2002). Finally, the following subsection examines the impact of mandatory shifting to annuitization at a specific age. This is currently required in tax qualified German Riester plans at the age of 85 and for UK income drawdown plans at the age 75 .

\section{Optimized Withdrawal Rules in a Risk-Return Context}

To evaluate how the relative ranking of the alternative withdrawal rules might change with 
an endogenous asset mix in the retiree's investment fund and other plan design parameters, it is useful to define the expected present value of the shortfall, called here "EPVShortfall":

$$
\text { EPVShortfall }=\sum_{t=0}^{l-x} \frac{{ }_{t} p_{x} S E\left(\mathrm{~B}_{\mathrm{t}}\right)}{\left(1+R_{f}\right)^{t}}
$$

Here, $\operatorname{SE}\left(B_{t}\right)=\mathrm{E}\left[\max \left(z-B_{t}, 0\right)\right]$ denotes the expected shortfall with respect to the target $z$, which is the benefit flow of the benchmark life annuity. Possible expected shortfalls are weighted by the conditional probability ${ }_{t} p_{x}$ that a man aged $x$ at the beginning of the retirement phase is still alive, if a shortfall occurs. All possible expected shortfalls are discounted back to the beginning of the retirement period using the risk-free interest rate $R_{f}$ (i.e. assuming a flat term structure of real interest rates) and summed over the maximum length of the mortality table used. This useful summary measure of the risk associated with a phased withdrawal strategy may be interpreted as the lump sum premium that would be required for the retiree to transfer this shortfall risk to an insurer, assuming actuarially fair pricing and no additional loading. Given this function, we minimize it with regard to asset allocation and other plan design parameters, to derive the patterns most amenable to alternative withdrawal rules.

Previous studies, most notably Milevsky (1998), Milevsky and Robinson (2000) and Albrecht and Maurer (2002), approach the issue of optimal fixed benefit withdrawal rules by adopting the criterion of controlling the probability of a consumption shortfall in retirement. On the other hand, as we have argued, this perspective does not account the timing and magnitude of the loss when it happens, which our risk measure does. To extend the approach, we propose two additional reward measures associated with each optimized phased withdrawal strategy, namely, the expected present value of benefits received during life (EPVBenefits) and the expected present value of bequests at death (EPVBequest). These are defined, respectively, as: 


$$
\begin{aligned}
& \text { EPVBenefits }=\sum_{t=0}^{l-x} \frac{{ }_{t} p_{x} E\left(\mathrm{~B}_{\mathrm{t}}\right)}{\left(1+R_{f}\right)^{t}}, \text { and } \\
& \text { EPVBequest }=\sum_{t=1}^{l-x} \frac{{ }_{t-1} p_{x} q_{x+t} E\left(\mathrm{~V}_{\mathrm{t}}\right)}{\left(1+R_{f}\right)^{t}}
\end{aligned}
$$

Here, the EPVBenefits is similar to the money's worth concept used by Mitchell et al. (1999); it reflects the expected present value of benefit payments conditional on survival. Finally, EBVBequest measures the expected present value of the inheritance that the retiree would pass on to heirs in the event of his death. ${ }^{5}$

Using these, we develop two optimized rules, namely the "Fixed Percent Optimized" rule, and the "1/T Optimized" rule. The first minimizes the expected present value of the shortfall by jointly selecting the optimal constant withdrawal fraction and an asset allocation. This relaxes the constant withdrawal rule mentioned earlier by endogenizing the withdrawal fraction. Compared to the non-optimized Fixed Percent rule, we expect that having two additional parameters, the fraction consumed as well as the asset allocation, will be more successful in controlling both mortality and capital market risk. The second rule, denoted as "1/T Optimized," minimizes the EPVShortfall by jointly selecting the maximum duration of the plan conditional on survival, and the asset allocation. We expect that the $1 / \mathrm{T}$ Optimized rule will permit more consumption when the probability is high that the retiree remains alive, as compared to the non-optimized 1/T rule, but it will also offer lower expected bequests.

\section{Comparative Results: Annuity versus Phased Withdrawal Plans}

\footnotetext{
${ }^{5}$ These metrics are useful as compared to a specific utility function for several reasons. First, the risk measures are consistent with expected utility analysis, since they are the primitives that enter into utility maximizers' objective functions. For example, one could imagine that a retiree trades off expected benefit payments versus the expected shortfall vis $a$ vis the benchmark annuity; this risk value model is consistent with a utility function suggested by Fishburn (1977). Further any particular functional form must embody specific tradeoffs between risk and return components, whereas our approach can remain agnostic about the specific weights attached to each (Sarin and Weber 1993). Also, risk minimization is consistent with many prior studies (c.f. Albrecht and Maurer, 2002; Chen and Milevsky, 2003; Milevsky and Robinson, 1994), and it is also consistent with conventional wisdom offered by financial planners when providing advice regarding retirement income payouts (c.f. Ameriks, 2004; Ameriks et al., 2001; Ibbotson Associates, 2003).
} 
Table 1 report results for the various withdrawal rules of interest, allowing optimized asset allocation. These may be compared to the benchmark case of a life annuity benefit given in Row 1; here, we find that a 65 -year old male who paid $€ 100$ for an immediate real annuity will receive annual benefits of $€ 5.82$ for life. By construction, both the EPVShortfall and EPVBequest are zero for the annuity purchase; the EPVBenefits measure is slightly below $€ 100$ due to the annuity load assumed. Row 2 reports results for a phased withdrawal program where the Fixed Benefit is set equal to the annuity at $€ 5.82$ as before; of course, the retiree may run short of funds. The optimized asset allocation associated with minimizing the EPVShortfall for this Fixed Benefit withdrawal plan consists of $25 \%$ stocks and $75 \%$ bonds, and associated with this plan is an expected shortfall worth $€ 3.24$ per $€ 100$ of initial assets. As long as the retiree lives, he can expect benefits totaling $€ 93.87$ (in present value). The present value of the bequest that his heirs can expect is quite large, at $€ 54.67$ (or more than half the initial investment). Clearly, unless the retiree has an enormous taste for bequests, annuitization would be judged far superior to taking a fixed benefit at $5.82 €$ per annum until the fund is likely exhausted.

\section{Table 1 here}

Rows 3 and 4 of Table 1 display results for two Fixed Percentage strategies. The first is determined by selecting a fixed percentage rule that pays out a first-year benefit equivalent to the $€ 5.82$ real lifelong annuity payable to a 65 -year old male paying $€ 100$. Given this constant benefitwealth-ratio (i.e. $\omega=5.82 \%$ ), we solve for the optimal asset mix minimizing the EPVShortfall. The second strategy selects a fixed fraction that is now also optimized with regard to EPVShortfall. What is different here is that both the asset allocation and the withdrawal fraction are simultaneously optimized at the beginning of the retirement phase. These two rows indicate that, in both cases, the risk measured by the EPVShortfall is almost four times as large as under the Fixed Benefit approach. Offsetting this could be the higher benefit stream conditional on survival and higher 
bequest value to the heirs. Both fixed percentage strategies have slightly higher equity exposures (about 35\%) than the fixed benefit approach (25\%). This contrasts with the high equity exposures recommended by Albrecht and Maurer (2002) and Vora and McGinnes (2000) who use a fixed benefit withdrawal approach. Of course, an optimized strategy that permits a fixed percentage payout of $7 \%$ of the account annually has a lower expected shortfall and higher expected benefits than the non-optimized strategy.

Next we turn to the two $1 / \mathrm{T}$ rules, where again the first simply sets $\mathrm{T}$ to the maximum plan duration (the oldest age in the mortality table), and optimizes asset allocation so as to minimize the EPVshortfall. The second rule endogenously evaluates both the asset allocation and the plan duration that minimizes EPVShortfall. It is interesting that the simple 1/T rule (Row 5) results in the highest equity exposure, and it is also unlikely to be preferred by many: this is because the size of the expected shortfall is the largest of those considered (€34 of the initial $€ 100$ asset), and the expected benefits are the lowest of those examined. The only clear gainers are likely to be the heirs. We contrast this with the pattern that would result from optimizing the maximum plan duration, which the retiree could do if he had Social Security or welfare to live on in the event that his asset were extinguished but he were still alive. This would occur around age 87, according to the program computed. Row 6 indicates using the 1/T rule optimized for asset allocation and the date of running out of assets offers lower risk, higher expected than the annuity, a reasonable bequest, and the asset allocation is not too risky ( $16 \%$ equity and $84 \%$ bonds).

Finally we turn to Row 7 for the 1/E(T) rule, which is consistent with the phased withdrawal scheme for 401(k) pension plans allowed by the US tax authority. This is an interesting strategy, because it offers quite low expected shortfalls and $8 \%$ higher expected benefits than the life annuity, while still affording a decent bequest potential. The asset allocation implied is rather conservative, with $22 \%$ in equity and $78 \%$ in bonds. Overall, looking across the phased withdrawal plans, there is 
no clearly dominant strategy, since all involve tradeoffs between risk, benefit, and bequest measures, and individual preferences may vary. Nevertheless, the $1 / \mathrm{E}(\mathrm{T})$ rule seems relatively appealing as compared to the others, as long as the retiree has only a moderate appetite for bequests.

The second panel of Table 1 reports results for a female age- 65 retiree considering the same phased withdrawal patterns. To summarize results, we find that women generally confront lower expected shortfall risks and anticipate higher EPVBenefits. This is because lower female mortality translates into a lower initial annuity payment; i.e. her actuarially fair benefit is $€ 5.02$ per year for a $€ 100$ purchase (versus the male payout of $€ 5.82$ ). Consequently, variable withdrawal plans have the woman withdraw less early in life, leaving more assets in the fund to earn future capital market returns. Since the woman also is expected to live longer, she will more likely be alive to reap the fruits of the investment. We would therefore predict, and the results confirm, that the $1 / \mathrm{E}(\mathrm{T})$ rule is more attractive to women than men, since it offers rather low expected shortfalls, and 20\% higher expected benefits as compared to the annuity, while still affording a decent bequest potential. It is also interesting that the asset allocation strategies for women are similar to those for men.

Thus far, the analysis has assumed the retiree begins the payout phase at age 65 , but it may be of interest to explore how phased withdrawal patterns might change for alternative retirement ages. Table 2 displays the findings for a male retiring at age 60 or age 70 , which can be directly compared with the top panel of Table 1 . The results show that the phased withdrawal patterns are unambiguously more attractive for an age-60 retiree, as compared to the 65 -year old. In other words, all expected shortfall risk measures are lower, expected benefit payouts to the living retirees are higher, and expected bequests are similar; furthermore, the portfolios are slightly lighter in equities. This is because the mortality drag for the life annuity purchased by a younger person, and therefore the benchmark, is substantially lower. By contrast, higher mortality faced by a 70-year old retiree produces a higher benchmark annuity which translates into greater EPVShortfalls, lower 
expected benefits, and also lower expected bequests. This is despite having $10-15 \%$ higher equity exposure. This leads us to conclude that annuitization would be relatively more appealing to older retirees, as compared to phased withdrawal patterns.

\section{Table 2 here}

Thus far the annuity benchmark has been computed using the sex-specific mortality table relevant to the individual making the purchase. But in some contexts, insurers are required to use a "unisex" mortality table when pricing annuities: for example, this is true in the US if an annuity is purchased with company-based pension accumulations (McGill et al., 2004). Likewise in the UK, unisex tables are used to price annuities in the Personal Pension arrangements. A unisex mortality table is generated by averaging mortality probabilities for men and women at each age. Naturally, such a table boosts the annuity paid to a female retiree and reduces the male's benefit, as compared to using sex-specific tables. In our context, if German mortality tables were used to value unisex payouts (as per Appendix A), a €100 annuity purchased by a female would have benefit payouts that are $7 \%$ higher than otherwise, whereas payments to the male would be $7.7 \%$ lower.

Yet the surprise is that women are not necessarily gainers, depending on the phased withdrawal pattern selected. This is because adopting a unisex table for annuitization changes the annuity payout benchmark, while the phased withdrawal plan still embodies the purchaser's sex-specific mortality table. Table 3 illustrates this case, where the annuity benefit is now (by construction) equal for men and women, at $€ 5.37$ annually for a $€ 100$ purchase. For men, expected shortfalls under all withdrawal patterns are lower, expected benefits are lower, and bequests are higher. The pattern is the opposite for women: expected shortfalls are higher, expected benefits are higher, and bequests lower. In other words, if a government mandated a unisex table for annuity pricing yet it still permitted phased withdrawal patterns, the woman who elected the phased withdrawal will be 
exposed to greater risk. This is likely a result that would be surprising to those who advocate unisex tables in retirement accounts.

Table 3 here

\section{Phased Withdrawal Plans with Mandatory Deferred Annuities.}

The results above suggest that some retirees might prefer to engage in a mixed strategy that is, to undertake phased withdrawals during the early portion of the retirement period and then to switch to an annuity thereafter. Furthermore, some researchers have suggested that such a mixed strategy would be attractive: it enhances the payout early on, in exchange for relatively low risk, and it also adds the insurance feature later in life (Blake et al., 2003; Milevsky, 1998). In addition, as noted earlier, some governments have recently required that the elderly annuitize after a phased income drawdown period.

To examine the risks and rewards associated with phased withdrawal followed by mandatory annuitization at some later age, we now revisit our calculations under each withdrawal rule but assume that annuity purchase is required if the individual is still alive at either age 75 or 85 . Two approaches are considered. In the first case, which we call the "switching strategy", a retiree would follow the relevant phased withdrawal rule until reaching the mandatory switching age. Again as the benchmark, we use the real annuity that the retiree could have purchased at age 65 , to compare our new results with prior findings. If, at the switching point, the fund is inadequate to purchase this real annuity, the gap represents a shortfall; conversely, if the account holds more than is needed to buy the benchmark annuity, this excess can be allocated to increase the bequest or used for higher consumption. In the following, we assume that an excess (if any) is used to increase the level of the annuity starting at age 75 or 85 , enhancing the EPVBenefits rather than EPVBequest measure. For the second case, we examine an "immediate purchase deferral strategy". In this case, the retiree purchases an annuity on retirement, with deferred payouts beginning at age 75 (or 85). The deferred 
annuity benefit is set equal to the benchmark that the retiree could have received if he initiated annuity payments at age 65 . It is worth noting that it is unclear what one might expect from these switching strategies, in terms of risks and rewards. Some analysts suggest that switching may be a preferred strategy, relying on the fact that the mortality drag rises with age; annuities pay out more for a given premium, the older one is when purchasing them (Milevsky, 2001). On the other hand, that analysis focuses only on the probability of a shortfall but does not weight the size of the loss, conditional on the shortfall occurring. By delaying annuitization, the retiree can benefit from capital market returns if they are favorable, so benefit payments can be higher while he lives, or bequests higher if he dies. Yet delaying annuitization also exposes him to shortfall risk.

Table 4 reports findings for the male retiring at age 65 , making the decision to switch from a phased withdrawal to an annuity at either age 75 (or 85). Comparing results in Panel A of Tables 1 and 4, we see that if delayed annuitization is available, this generally increases the value of the EPVBenefits amount and shrinks the EPVShortfall, both of which are beneficial. The EPVBequest falls, indicating that the deferred annuitization strategy is likely to be most attractive to those seeking to secure consumption while alive, without completely stripping their heirs of some unexpended funds. In other words, the risk/return profile of the phased withdrawal plan that includes a delayed annuity is enhanced, as compared to no annuity, at the cost of a smaller bequest potential. Also interesting is the fact that switching to an annuity later in life (i.e. at age 85; compare panels A and B in Table 4) raises the equity share of the portfolio slightly, but greatly enhances the bond exposure. Also, buying the annuity later obviously promise more bequest potential, at the cost of higher shortfall.

Table 4 here

Table 5 displays results for a 65 -year old male purchasing a deferred annuity at the beginning of the retirement period, with annuity payouts commencing at age 75 (or 85) assuming he is 
alive. In contrast to the mandatory annuitization strategy, we see that the risk and return profile depends heavily on the chosen withdrawal rule. In the case of the $1 / T$ rule combined with a deferred annuity payable from age 75 , the logical strategy is to consume all remaining wealth using the phased withdrawal tactic by age 74 , secure in the knowledge that one is protected against longevity risk thereafter. This pattern provides a benefit stream worth slightly more than the real annuity, and it offers low shortfall risk and low expected bequests. This is an important result since it indicates the advantage of allowing flexibility until age 75 , paired with protected consumption after that age. Similar results hold if the deferred annuity were to begin at age 85 , with slightly higher benefit and bequest levels at the expense of somewhat higher shortfalls. By contrast, the $1 / \mathrm{E}(\mathrm{T})$ rule combined with a deferred annuity at age 75 provides the retiree with relatively low payouts up to age 75 , producing a high EPVShortfall, but after that age, benefits flow from both the annuity and the phased withdrawal plan which raises EPVBenefits (and higher potential bequests). Delaying the annuity payout date to age 85 instead of 75 exposes the retiree to much higher shortfall risk, along with higher possible wealth for the heirs.

\section{Table 5 here}

\section{Comparative Results}

In additional analyses not reported here (but available on request), we have also explored the sensitivity of our results to a range of alternative capital and annuity market scenarios. An interesting experiment develops the environment that might be relevant to US retirees: here, life expectancy is longer than in Germany, loadings are lower, and the capital market presents different risk/return characteristics. In this simulation, we use the US Annuitant 2000 Basic Male mortality table along with means and standard deviations for stocks, bonds, and cash using Ibbotson Associates data over the period 1967-2004 (the same period over which we take the German capital market parameters). While annuity payouts are quite similar across the two countries, capital markets display different 
characteristics: the mean returns on stocks and bonds is slightly lower in the US than Germany, but volatility on stocks is much lower in the US (about $17 \%$ instead of $25 \%$ in Germany), and it is much higher on bonds (about 11\% versus 5\% in Germany). Under these assumptions, we re-optimize the withdrawal rules and find, for all withdrawal plans, that the US retiree would hold a much higher level of equity exposure in the risk-minimizing portfolio. Nevertheless, the withdrawal fractions are not much affected for the $1 / \mathrm{T}$ and the Fixed Percentage rules. This is accompanied by a higher shortfall risk, higher expected benefits, and comparable expected bequests, driven by the fact that bonds are riskier in the US than in Germany.

\section{Summary and Concluding Remarks}

Standard economic models imply that retirees would tend to value highly the protection against longevity risk that annuitization offers, but the evidence suggests that many retirees do not purchase annuities with their disposable wealth, perhaps because they anticipate leaving a bequest. As a result, there is a need for models that can guide retirees as they examine tradeoffs between consumption versus the possibility of leaving a bequest during the asset drawdown phase. Of course, these tradeoffs require a retired worker to exchange some risk for some return, offering a natural role for phased withdrawal programs during the retirement period.

Our approach uses the concept of shortfall-risk, whereby the benefit of a life annuity serves as the benchmark. We extend previous research in two directions. First, we use a risk metric which considers both the probability as well as the size of a consumption shortfall when it occurs. Second, we focus not only on phased withdrawal plans with fixed benefits, but also on variable benefit patterns in conjunction with a predetermined benefit-to-wealth ratio. We investigate several phased withdrawal strategies, assessing the success of withdrawal rules while allowing for endogenous asset allocation patterns, and we also allow the worker to make decisions both about when to retire and when to switch to an annuity. Of course, selecting any specific withdrawal pattern requires fur- 
ther information on utility weights that balance own consumption against bequests, but many retirees and their financial counselors may find it difficult to articulate their utility functions in advance. For this reason, we believe it is useful to explore various explicit risk and return measures for alternative withdrawal plans, allowing for randomness in both the time of death and investment returns. ${ }^{6}$ Our model offers several novel conclusions which may be useful for professional financial planers helping clients make retirement investment choices:

- Discretionary management of accumulated assets with systematic phased withdrawals for consumption purposes offers the advantages of flexibility, bequests, and possibly higher rates of consumption than under a standard life annuity. However, phased withdrawal plans also require the retiree to dedicate effort to formulating asset allocation and withdrawal rules.

- A phased withdrawal plan that minimizes the risk of consuming less than the real annuity benchmark will allocate retirement assets more to fixed income than to equities. Nonetheless, the specific mix elected will depend on plan design, age, and mortality risk, among other factors.

- A phased withdrawal strategy paying the same benefit as an annuity exposes the retiree to the risk of outliving his assets while still alive. A phased withdrawal plan using a fixed benefit-towealth ratio avoids the risk of running out of money, since benefits fluctuate in tandem with the pension fund's value. But the fixed benefit withdrawal rule affords lower risk than variable withdrawal rules, if one uses a mortality-weighted shortfall-risk measure (which includes both shortfall probability and magnitude of loss).

- Mandatory deferred annuitization with a fixed withdrawal rule can enhance expected payouts and cut expected shortfall risk but at the cost of reduced expected bequests, as compared to no annuity. For a variable withdrawal plan, a simple deferred annuitization may not reduce risk: rather, it requires optimization of the benefit to wealth ratio.

- The optimized $1 /$ T rule and the fixed benefit rule both have appealing risk characteristics, particularly when combined with a mandatory deferred annuity.

- As a standalone strategy, the $1 / \mathrm{E}(\mathrm{T})$ phased withdrawal rule is appealing since it offers a relatively low expected shortfall risk, good expected payouts for the retiree during his life, and some bequest potential for his heirs. But when mandatory annuities are combined with a phased withdrawal plan, the $1 / \mathrm{E}(\mathrm{T})$ rule becomes less attractive.

\footnotetext{
${ }^{6}$ Taking risk and value as primitives is appealing for several reasons, as expressed by Brachinger and Weber (1997). From a descriptive perspective, a risk-value model such as ours is likely to be useful in explaining retiree preferences by understanding how they trade off expected benefits, bequests, and the risk of consumption shortfalls. Policymakers and regulators may benefit from evidence on the risk-return patterns of different withdrawal options in tax-favored individual retirement plans. Financial institutions offering retirement products such as banks, insurance companies, and mutual funds, can use this information to design and market products that have typical benefit, bequest, and risk features.
} 
- Some advocate unisex mortality tables, seeing them as "fairer" to women; however our model shows that if phased withdrawal plans are available as an alternative, unsex tables make women bear more risk compared to annuitization.

These findings also have general relevance for national retirement policy in Europe and the Americas. As one example, the $1 / \mathrm{E}(\mathrm{T})$ rule is used by the US tax authority for the "default" withdrawal pattern in defined contribution accounts (including $401 \mathrm{k}$ plans). Our results show that this is a relatively appealing standard in the US context, where retirement plan annuitization is not mandatory. Mandating annuitization after a phased withdrawal period can also be quite appealing in terms of risk, so it is interesting that this approach has recently been implemented in both the UK and Germany, and it has been recommended in the US by the recent Commission to Strengthen Social Security (Cogan and Mitchell, 2003). Our results also suggest that government mandates requiring unisex tables for annuity pricing (as in the UK) expose women to greater risk if they elect a phased withdrawal plan. Finally, our results imply that retiree portfolios will optimally include more fixed income if the retiree plans on annuitizing later. 


\section{References}

Albrecht, P., \& Maurer, R. (2002). Self-Annuitization, Consumption Shortfall in Retirement and Asset Allocation: The Annuity Benchmark. Journal of Pension Economics and Finance, 1, 269-288.

Ameriks, J. (2004). How Do Retirees Go From Stock to Flow? Pension Design and Structure: New Lessons from Behavioral Finance, eds. Olivia S. Mitchell and Stephen P. Utkus. Oxford, Oxford University Press.

Ameriks, J., Veres, R. \& Warshawsky, M. J. (2001). Making Retirement Income Last A Lifetime. Journal of Financial Planning, December, 60-76.

Artzner, P., Delbaen, F., Eber, J. M. \& Heath, D. (1999). Coherent Measures of Risk. Mathematical Finance, 9, 203-238.

Bawa, V. S. (1978). Safety-First, Stochastic Dominance, and Optimal Portfolio Choice. Journal of Financial and Quantitative Analysis, 13, 255-271.

Bengen W.P. (1994). Determining withdrawal rates using historical data. Journal of Financial Planning, 7 (4), 171-182.

Bengen W.P. (1996). Conserving Client Portfolios During Retirement, Part III. Journal of Financial Planning, 10 (6), 84-97.

Blake, D., Cairns, A. J.G., \& Dowd, K. (2003). PensionMetrics 2: Stochastic Pension Plan Design During the Distribution Phase. Insurance, Mathematics and Economics, 33, 29-47.

Bodie, Z. (2001). Financial Engineering and Social Security Reform. In: J.M. Campbell \& M. Feldstein (ed.), Risk Aspect of Investment-Based Social Security Reform, National Bureau of Economic Research Conference Report, 291-320.

Börsch-Supan, A., Heiss, F., Ludewig, A. \& Winter, J. (2003). Pension Reform, Capital Market and the Rate of Return. German Economic Review, 4, 151-181.

Brachinger, H.W. \& Weber, M. (1997). Risk as a Primitive: A Survey of Measures of Perceived Risk. ORSpektrum, 19, 235-250.

Brown, J. \& Poterba, J. M. (2000). Joint Life Annuities and Annuity Demand by Married Couples. Journal of Risk and Insurance, 67, 527-556.

Brown, J., Mitchell O. S., Poterba, J. M., \& Warshawsky, M. J. (2001). The Role of Annuity Markets in Financing Retirement. Cambridge, MA, MIT Press.

Brown, J., Mitchell O. S., Poterba, J. M., \& Warshawsky, M. J. (1999). Taxing Retirement Income: Nonqualified Annuities and Distributions from Qualified Accounts. National Tax Journal, LII (3), September, 563-592.

Brugiavini, A. (1993). Uncertainty Resolution and the Timing of Annuity Purchases. Journal of Public Economics, 50, 31-62.

Campbell, J. Y., Cocco, J., Gomes, F., Maenhout, F. \& Viceira, L. M. (2001). Stock Market Mean Reversion and the Optimal Equity Allocation of a Long-Lived Investor. European Finance Review, 5, 269-292.

Campbell, J Y. \& Viceira, L. M. (2002). Strategic Asset Allocation. Oxford, Oxford University Press.

Canner, N., Mankiw, G. \& Weil, D. (1997). An Asset Allocation Puzzle. American Economic Review, 87(1), 181-191.

Chen, P. \& Milevsky, M. (2003). Merging Asset Allocation and Longevity Insurance: An Optimal Perspective on Payout Annuities. Journal of Financial Planning, 16(6), 52-62.

Cogan, J. \& Mitchell, O. S. (2003). Perspectives from the President's Commission on Social Security Reform. Journal of Economic Perspectives, 17(2), 149-172.

Feldstein, M., Ranguelova, E. \& Samwick, A.. (2001). The Transition to Investment-Based Social Security When Portfolio Returns and Capital Profitability are Uncertain. In Risk Aspects of Investment-Based Social Security Reform. Chicago. University of Chicago Press, 41-81.

Fishburn, P. C. (1977). Mean Risk Analysis Associated with Below Target Return. American Economic Review, 67, 116-126.

Fishburn, P. C. (1982). Foundations of Risk Measurement. II. Effects of Gains on Risk. Journal of Mathematical Psychology, 25, 226-242. 
Fishburn, P. C. (1984). Foundations of Risk Measurement I: Risk as Probable Loss. Management Science, 30, 396-406.

Ho, K., Milevsky, M. \& Robinson, C. (1994). Asset Allocation, Life Expectancy and Shortfall. Financial Services Review 3, 109-126.

Hugen, J.C., Laatsch, F.E. \& Klein, D.P. (2002). Withdrawal Patterns and Rebalancing Cost for Taxable Portfolios. Financial Services Review 11, 341-366.

Ibbotson Associates. (2003). Why Investors Should Consider Lifetime Payout Annuities in Retirement. A Report to NAVA. Chicago, Ibbotson Associates.

Kahneman, D. \& Tversky, A. (1979). Prospect Theory: An Analysis of Decisions Under Risk. Econometrica, 1979, 263-291.

Kataoka, S. (1963). A Stochastic Programming Model. Econometrica, 31, 191-196.

Kotlikoff, L. \& Spivak, A. (1981). The Family as an Incomplete Annuities Market. Journal of Political Economy, 89, 372-391.

Laughhunn, D., Payne, J. W. \& Crum R. (1980). Managerial Risk Preferences for Below-Target-Returns. Management Science, 26, 1238-1249.

Leibowitz, M. L., Kogelman, S. \& Bader, L. N. (1996). Asset Allocation under Shortfall Constraint. Journal of Portfolio Management, Winter, 18-23.

Leibowitz, M. L. \& Krasker, W.S. (1988). The Persistence of Risk: Stocks versus Bonds over the Long Term. Financial Analysts' Journal, November/December, 40-47.

Libby, R. \& Fishburn, P.C. (1977). Behavioral Models of Risk Taking in Business Decisions: A Survey and Evaluation. Journal of Accounting Research, 15, 272-292.

March, J. G. \& Shapira, Z. (1987). Managerial Perspectives on Risk and Risk Taking. Management Science, 33, 1404-1418.

Maurer, R. \& Schlag, C. (2003). Money-Back Guarantees in Individual Pension Accounts: Evidence from the German Pension Reform. In The Pension Challenge: Risk Transfers and Retirement Income Security, eds. Olivia S. Mitchell and Kent Smetters. Oxford: Oxford University Press, 187-213.

McGill, D., Brown, K., Haley, J. \& Schieber, S. (2004). Fundamentals of Private Pensions, 8e. Philadelphia, University of Pennsylvania Press.

Merton, R. C. (1971). Optimum Consumption and Portfolio Rules in a Continuous Time Model. Journal of Economic Theory 8, 323-361.

Milevsky, M. (1998) Optimal Asset Allocation Towards The End of the Life Cycle: To Annuitize or Not to Annuitize? Journal of Risk and Insurance 65, 401-426.

Milevsky, M. (2001). Optimal Annuitization Policies: Analysis of the Options. North American Actuarial Journal, 5, 57-69.

Milevsky, M., Ho, K., \& Robinson, C. (1997). Asset Allocation Via the Conditional First Exit Time or How to Avoid Outliving Your Money. Review of Quantitative Finance and Accounting, 9, 53-70.

Milevsky, M. \& Robinson, C. (1994). Asset Allocation, Life Expectancy and Shortfall. Financial Services Review, 3, 109-126.

Milevsky, M \& Robinson, C. (2000). Self-Annuitization and Ruin in Retirement. North American Actuarial JournaI, 4, 113-129.

Milevsky, M. \& Young, V. (2003). Annuitization and Asset Allocation. Working Paper IFID Centre, The Schulich School of Business, December, [11.02.2005 http://www.ifid.ca/pdf_workingpapers/WP2003OCT15.pdf]

Mitchell, O. S.; Poterba, J. M., Warshawsky, M. J. \& Brown, J. R. (1999). New Evidence on the Money's Worth of Individual Annuities. American Economic Review December, 1299-1318.

Munnell, A. H., Sundén, A., Mauricio, A. \& Taylor, C. (2002). How Will The Rise In 401(K) Plans Affect Bequests? An Issue in Brief. Center for Retirement Research at Boston College. November, Number 10.

Pye, G. B. (2000). Sustainable Investment Withdrawals. Journal of Portfolio Management, Summer, 73 - 83.

Pye, G. B. (2001). Adjusting Withdrawal Rates for Taxes and Expenses. Journal of Financial Planning, April, 126 - 136.

Roy, A. (1952). Safety First and the Holding of Risky Assets. Econometrica, 20, 431-449. 
Sarin, R. K. \& Weber, M. (1993). Risk-value Models. European Journal of Operational Research 72, 135 149.

Vora, P. P. \& McGinnis, J. D. (2000). The Asset Allocation Decision in Retirement: Lessons from DollarCost Averaging. Financial Services Review, 9,: 47-63.

Winkler, R. L., Roodman, G. M. \& Britney, G. M.. (1972). The Determination of Partial Moments. Management Science, 19(3), 290-95.

Yaari, M. (1965). Uncertain Lifetime, Life Insurance, and the Theory of Consumer. Review of Economic Studies, 32, 137-150. 
Figure 1: Mean Benefit of Withdrawal Plan Conditional on Survival (50\% Equities / 50\% Bonds): Life Annuity Benchmark

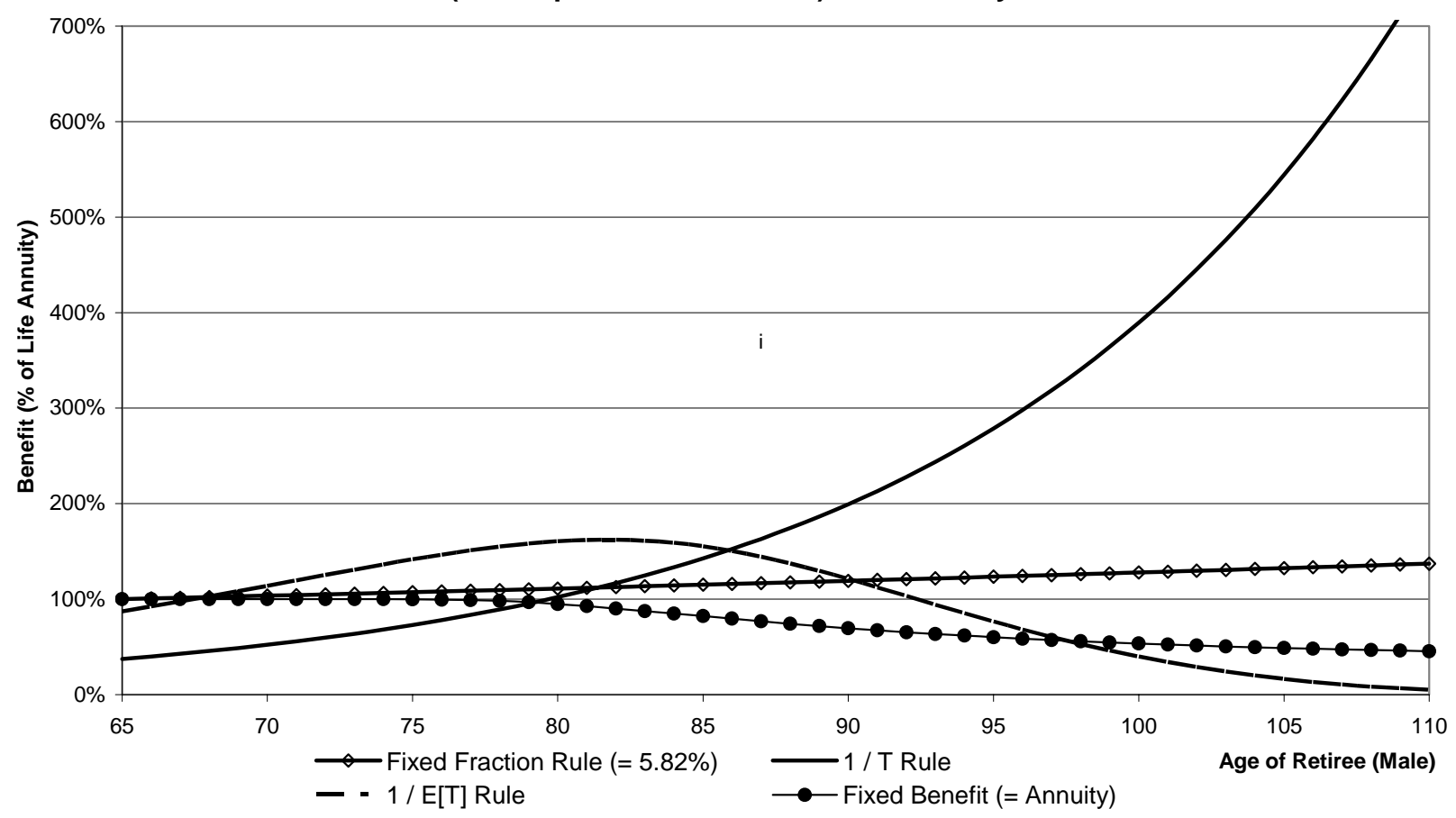

Source: Authors' calculations.

Figure 2: Shortfall Probability of Withdrawal Plan Conditional on Survival ( $50 \%$ Equities / $50 \%$ Bonds): Life Annuity Benchmark

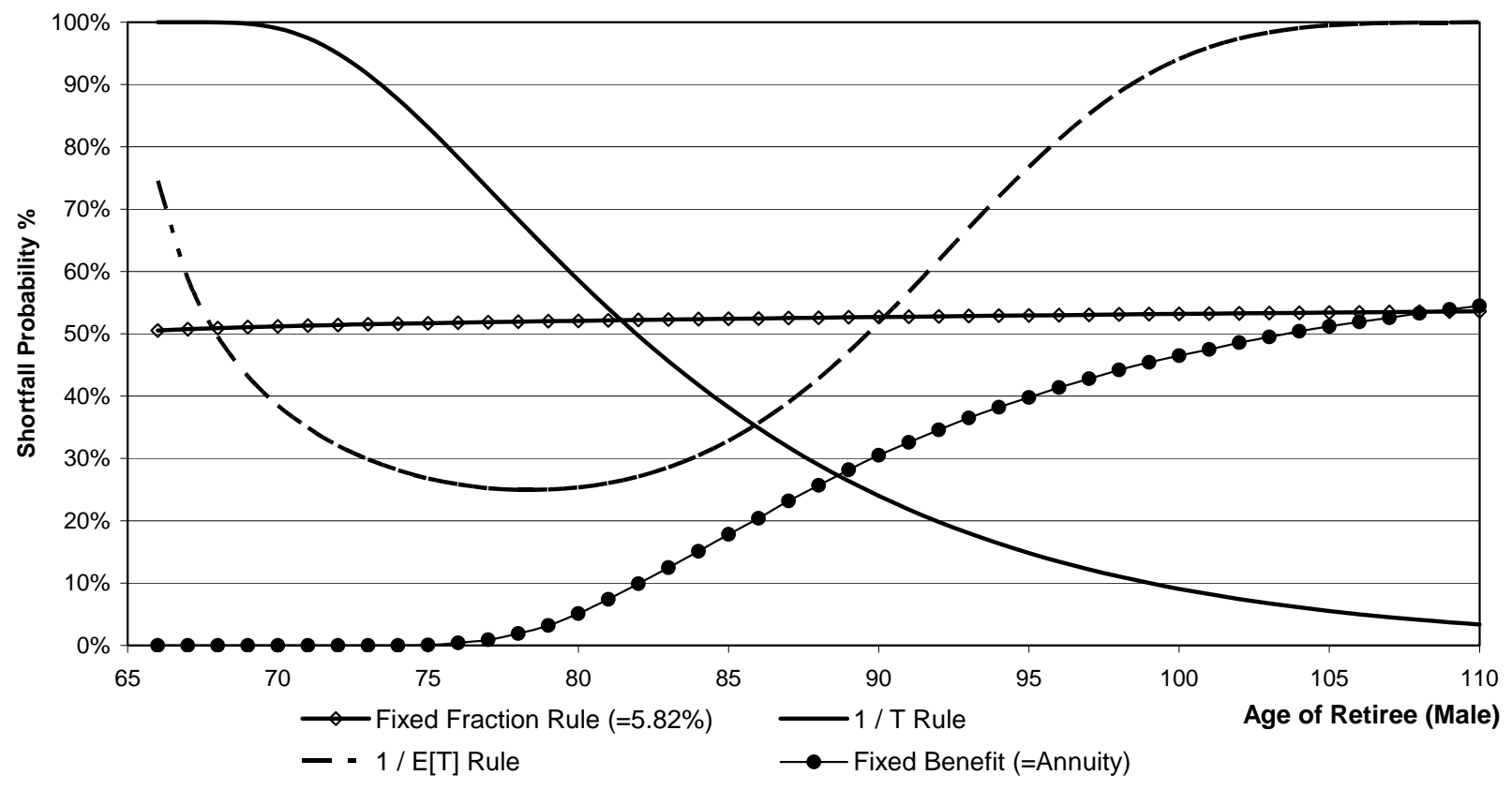

Source: Authors' calculations. 
Figure 3: Expected Shortfall of Withdrawal Plan Conditional on Survival (50\% Equities / 50\% Bonds): Life Annuity Benchmark

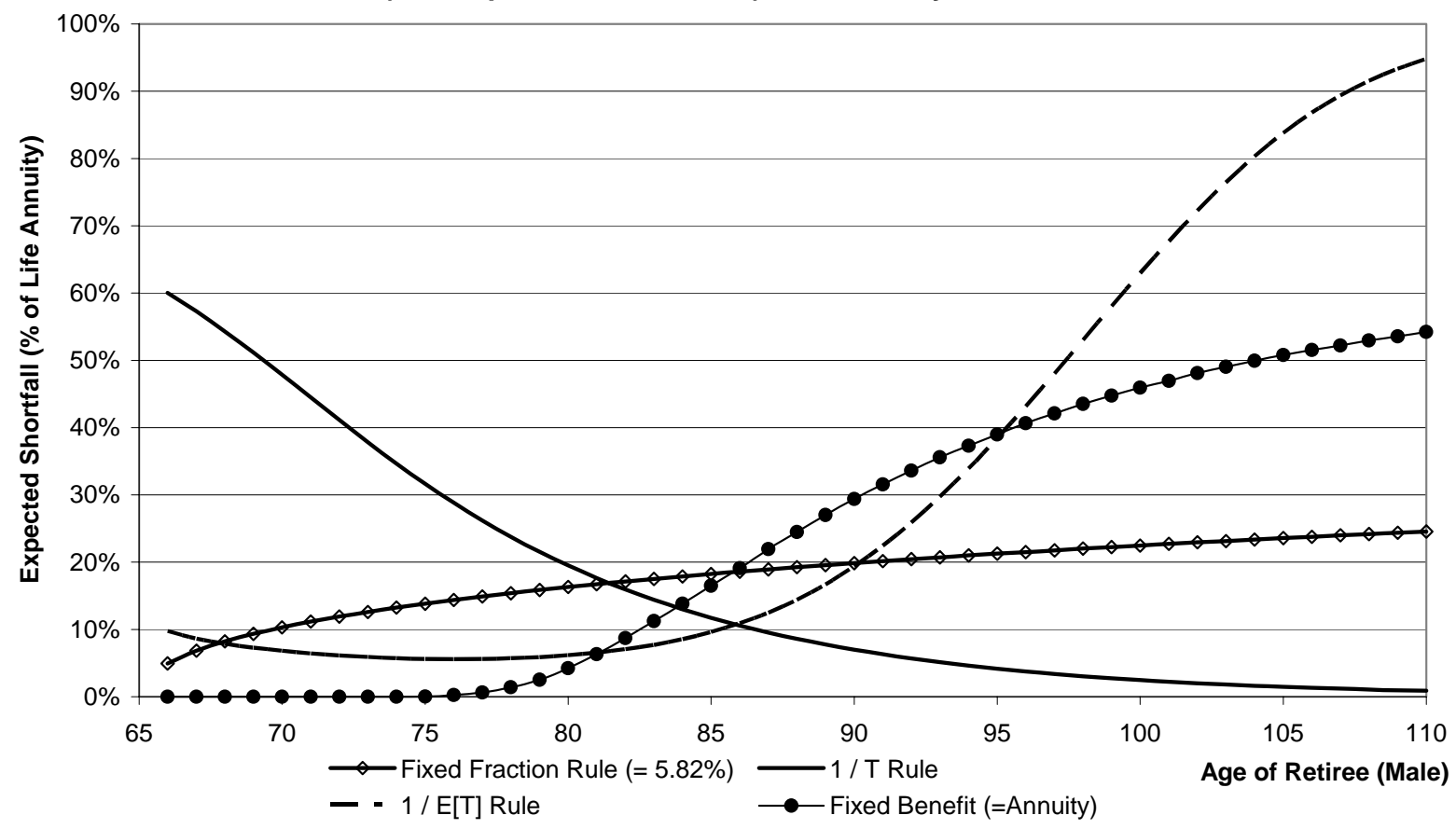

Source: Authors' calculations.

Figure 4: Mean Bequest of Withdrawal Plan Conditional on Death ( $50 \%$ Equities / $50 \%$ Bonds) as \% of Initial Capital

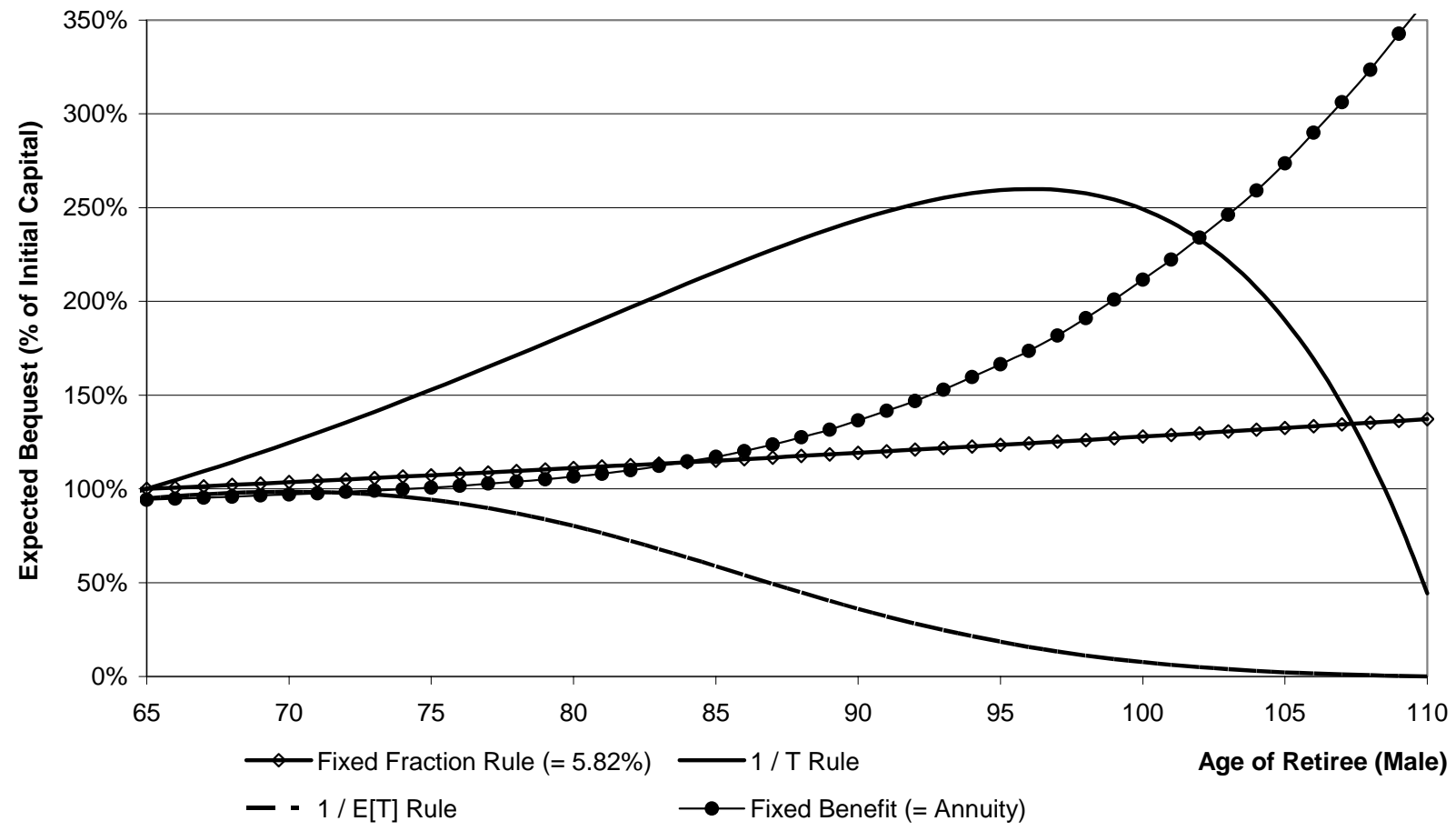

Source: Authors' calculations. 
Table 1. Results for Risk-Minimizing Phased Withdrawal Strategies

Using Sex-specific Mortality Tables for Annuity Pricing, Allowing Optimized Asset Allocation: Male and Female Retirees

\begin{tabular}{|c|c|c|c|c|c|}
\hline \multicolumn{6}{|c|}{ A. Results for Male (Retirement Age 65): Benchmark Real Life Annuity €5.82 p.a./ €100 } \\
\hline \multirow[t]{2}{*}{ Strategy } & \multirow{2}{*}{$\begin{array}{c}\text { EPV } \\
\text { Shortfall }\end{array}$} & \multirow{2}{*}{\begin{tabular}{c|} 
EPV \\
Benefits
\end{tabular}} & \multirow{2}{*}{$\begin{array}{c}\text { EPV } \\
\text { Bequest }\end{array}$} & \multicolumn{2}{|c|}{ Investment Weights (in \%) } \\
\hline & & & & Equity & Bonds \\
\hline 1. Real Annuity $€ 5.82$ & 0 & 97.291 & 0 & & \\
\hline 2. Fixed Benefit $=€ 5.82$ & 3.236 & 93.867 & 54.670 & 25 & 75 \\
\hline 3. Fixed Pct. $=5.82 \%$ & 11.611 & 95.969 & 70.218 & 34 & 66 \\
\hline 4. Fixed Pct. Opt $\omega=7.0 \%$ & 10.366 & 102.433 & 56.250 & 35 & 65 \\
\hline 5. 1/T Rule Age 110 & 33.726 & 92.696 & 154.583 & 59 & 41 \\
\hline 6. 1/T Rule Opt. Age 87 & 15.003 & 107.258 & 33.857 & 16 & 84 \\
\hline 7. 1/E(T) Rule & 7.797 & 105.400 & 40.924 & 22 & 78 \\
\hline \multicolumn{6}{|c|}{ B. Results for Female (Retirement Age 65): Benchmark Real Life Annuity $€ 5.02$ p.a./ $€ 100$} \\
\hline 8. Real Annuity $€ 5.02$ & 0 & 97.291 & 0 & & \\
\hline 9. Fixed Benefit $=€ 5.02$ & 8.447 & 101.044 & 73.378 & 27 & 73 \\
\hline 10. Fixed Pct. $=5.02 \%$ & 1.334 & 95.868 & 62.389 & 20 & 80 \\
\hline 11. Fixed Pct. Opt $\omega=6.1 \%$ & 7.134 & 108.465 & 57.482 & 28 & 72 \\
\hline 12. $1 /$ T Rule Age 110 & 25.601 & 106.508 & 137.088 & 46 & 54 \\
\hline 13. 1/T Rule Opt. Age 91 & 12.130 & 120.062 & 33.225 & 16 & 84 \\
\hline 14. 1/E(T) Rule & 5.375 & 116.899 & 36.903 & 19 & 81 \\
\hline
\end{tabular}

Notes:

EPV Shortfall: expected present value of future benefit payments below the life annuity (shortfall)

EPV Bequest: expected present value of future bequest payments

EPV Payments: expected present value of future benefit payments

Source: Authors' calculations.

Table 2. Results for Risk-Minimizing Phased Withdrawal Strategies

Using Sex-specific Mortality Tables for Annuity Pricing, Allowing Optimized Asset Allocation: Male Retirees Only

\begin{tabular}{|c|c|c|c|c|c|}
\hline \multicolumn{6}{|c|}{ A. Results for Male (Retirement Age 60): Benchmark Real Life Annuity $€ 4.95$ p.a/€100 } \\
\hline \multirow[t]{2}{*}{ Strategy } & \multirow{2}{*}{$\begin{array}{c}\text { EPV } \\
\text { Shortfall }\end{array}$} & \multirow{2}{*}{$\begin{array}{l}\text { EPV } \\
\text { Benefits }\end{array}$} & \multirow{2}{*}{$\begin{array}{c}\text { EPV } \\
\text { Bequest }\end{array}$} & \multicolumn{2}{|c|}{ Investment Weights (in \%) } \\
\hline & & & & Equity & Bonds \\
\hline Real Annuity $€ 4.95$ & 0 & 97.291 & 0 & & \\
\hline Fixed Benefit $=€ 4.95$ & 1.525 & 95.679 & 64.291 & 20 & 80 \\
\hline Fixed Pct. Opt $\omega=5.9 \%$ & 7.054 & 108.775 & 59.121 & 27 & 73 \\
\hline 1/T Rule Opt Age 87 & 13.073 & 120.157 & 35.915 & 17 & 83 \\
\hline 1/E(T) Rule & 5.700 & 116.120 & 40.293 & 19 & 81 \\
\hline \multicolumn{6}{|c|}{ B. Results for Male (Retirement Age 70): Benchmark Real Life Annuity $€ 7.03$ p.a./ $€ 100$} \\
\hline Real Annuity $€ 7.03$ & 0 & 97.291 & 0 & & \\
\hline Fixed Benefit $=€ 7.03$ & 6.174 & 90.759 & 50.432 & 40 & 60 \\
\hline Fixed Pct. Opt $\omega=8.5 \%$ & 14.416 & 96.022 & 53.415 & 45 & 55 \\
\hline 1/T Rule Opt. Age 87 & 17.505 & 96.163 & 35.129 & 17 & 83 \\
\hline 1/E(T) Rule & 11.282 & 96.305 & 42.575 & 29 & 71 \\
\hline
\end{tabular}

Note: See Table 1.

Source: Authors' calculations. 
Table 3. Results for Risk-Minimizing Phased Withdrawal Strategies

Using Unisex Mortality Tables for Annuity Pricing, Allowing Optimized Asset Allocation: Male and Female Retirees

\begin{tabular}{|c|c|c|c|c|c|}
\hline \multicolumn{6}{|c|}{ A. Results for Male (Retirement Age 65): Benchmark Real Life Annuity €5.37 p.a./ €100 } \\
\hline \multirow[t]{2}{*}{ Strategy } & \multirow{2}{*}{$\begin{array}{c}\text { EPV } \\
\text { Shortfall }\end{array}$} & \multirow{2}{*}{$\begin{array}{c}\text { EPV } \\
\text { Benefits }\end{array}$} & \multirow{2}{*}{$\begin{array}{c}\text { EPV } \\
\text { Bequest }\end{array}$} & \multicolumn{2}{|c|}{ Investment Weights (in \%) } \\
\hline & & & & Equity & Bonds \\
\hline Real Annuity $€ 5.37$ & 0 & 89.871 & 0 & & \\
\hline Fixed Benefit $€ 5.37$ & 1.738 & 88.168 & 58.726 & 20 & 80 \\
\hline Fixed Pct. Opt $\omega=6.6 \%$ & 7.407 & 98.382 & 57.773 & 30 & 70 \\
\hline 1/T Rule Opt.Age 88 & 11.503 & 104.756 & 36.565 & 14 & 86 \\
\hline $1 / \mathrm{E}(\mathrm{T})$ Rule & 4.818 & 103.767 & 40.135 & 20 & 80 \\
\hline \multicolumn{6}{|c|}{ B. Results for Female (Retirement Age 65): Benchmark Life Annuity $€ 5.37$ p.a./ $€ 100$} \\
\hline Real Annuity €5.37 & 0 & 104.206 & 0 & & \\
\hline Fixed Benefit $€ 5.37$ & 2.490 & 101.364 & 59.964 & 25 & 75 \\
\hline Fixed Pct. Opt $\omega=6.4 \%$ & 9.736 & 112.331 & 56.268 & 32 & 68 \\
\hline 1/T Rule Opt Age 91 & 15.287 & 122.828 & 34.048 & 20 & 80 \\
\hline $1 / \mathrm{E}(\mathrm{T})$ Rule & 8.107 & 118.884 & 37.730 & 21 & 79 \\
\hline
\end{tabular}

Note: See Table 1.

Source: Authors' calculations.

\section{Table 4. Results for Risk-Minimizing Phased Withdrawal Strategies Allowing Switching to} Life Annuities

Using Sex-specific Tables for Annuity Pricing, Allowing Optimized Asset Allocation and Withdrawal Fraction: Male Retirees Only

\begin{tabular}{|c|c|c|c|c|c|}
\hline \multicolumn{6}{|c|}{ A. Results for Male (Retirement Age 65 Switching Age 75): Benchmark Real Life Annuity €5.82 p.a./ €100 } \\
\hline \multirow[t]{2}{*}{ Strategy } & \multirow{2}{*}{$\begin{array}{c}\text { EPV } \\
\text { Shortfall }\end{array}$} & \multirow{2}{*}{$\begin{array}{c}\text { EPV } \\
\text { Benefits }\end{array}$} & \multirow{2}{*}{$\begin{array}{c}\text { EPV } \\
\text { Bequest }\end{array}$} & \multicolumn{2}{|c|}{ Investment Weights (in \%) } \\
\hline & & & & Equity & Bonds \\
\hline Real Annuity $€ 5.82$ & 0 & 97.291 & 0 & & \\
\hline Fixed Benefit until 75 & 1.411 & 108.883 & 13.779 & 15 & 85 \\
\hline Fixed Pct. Opt $\omega=6.8 \%$ & 2.856 & 109.434 & 13.019 & 12 & 88 \\
\hline 1/T Rule Opt Age 83 & 3.059 & 109.360 & 13.264 & 11 & 89 \\
\hline 1/E(T) Rule & 3.582 & 109.176 & 13.776 & 11 & 89 \\
\hline \multicolumn{6}{|c|}{ B. Results for Male (Retirement Age 65 Switching Age 85): Benchmark Life Annuity €5.82 p.a./ €100 } \\
\hline Real Annuity $€ 5.82$ & 0 & 97.291 & 0 & & \\
\hline Fixed Benefit until 85 & 2.580 & 104.590 & 39.988 & 30 & 70 \\
\hline Fixed Pct. Opt $\omega=7.4 \%$ & 6.831 & 110.559 & 32.727 & 26 & 74 \\
\hline 1/T Rule Opt Age 88 & 9.145 & 110.123 & 35.703 & 21 & 79 \\
\hline 1/E(T) Rule & 5.085 & 106.616 & 31.935 & 16 & 84 \\
\hline
\end{tabular}

Note: See Table 1.

Source: Authors' calculations. 
Table 5. Results for Risk Minimizing Phased Withdrawal Strategies with Immediate Purchase of Mandatory Deferred Life Annuities

Using Sex-specific Tables for Annuity Pricing, Allowing Optimized Asset Allocation and Withdrawal Fraction, Male Retirees Only

\begin{tabular}{|c|c|c|c|c|c|}
\hline \multicolumn{6}{|c|}{$\begin{array}{l}\text { A. Results for Male (Retirement Age } 65 \text { annuity deferred up to Age } 75) \text { : Benchmark Real Life Annuity } \\
€ 5.82 \text { p.a./ } € 100\end{array}$} \\
\hline \multirow[t]{2}{*}{ Strategy } & \multirow{2}{*}{$\begin{array}{l}\text { EPV- } \\
\text { Shortfall }\end{array}$} & \multirow{2}{*}{$\begin{array}{c}\text { EPV- } \\
\text { Benefits }\end{array}$} & \multirow{2}{*}{$\begin{array}{c}\text { EPV- } \\
\text { Bequest }\end{array}$} & \multicolumn{2}{|c|}{ Investment Weights (in \%) } \\
\hline & & & & Equity & Bonds \\
\hline Real Annuity $€ 5.82$ & 0 & 97.291 & 0 & & \\
\hline Fixed Benefit until 75 & 1.050 & 100.712 & 4.200 & 10 & 90 \\
\hline Fixed Pct. Opt $\omega=15.3 \%$ & 8.954 & 108:664 & $8: 944$ & 55 & 45 \\
\hline 1/T-Rule Opt Age 74 & $1: 469$ & $102: 390$ & $3: 710$ & 8 & 92 \\
\hline 1/E(T) Rule & $21: 291$ & $128: 127$ & $34: 783$ & 89 & 11 \\
\hline \multicolumn{6}{|c|}{$\begin{array}{l}\text { B. Results for Male (Retirement Age } 65 \text { annuity deferred up to Age 85): Benchmark Life Annuity } € 5.82 \\
\text { p.a./ €100 }\end{array}$} \\
\hline Real Annuity $€ 5.82$ & 0 & 97.291 & 0 & & \\
\hline Fixed Benefit until 85 & 1.771 & 101.730 & 27.606 & 20 & 80 \\
\hline Fixed Pct. Opt $\omega=8.7 \%$ & 10.291 & 107.818 & 36.586 & 39 & 61 \\
\hline 1/T-Rule Opt Age 84 & 6.917 & 108.891 & 21.820 & 17 & 83 \\
\hline 1/E(T) Rule & 10.166 & 105.603 & 35.704 & 25 & 75 \\
\hline
\end{tabular}

Note: See Table 1

Source: Authors' calculations. 


\section{Appendix A: Determining Annuity Benefits}

Using the actuarial principle of equivalence, we estimate the gross single premium of the annuity by calculating the present value of expected benefits paid to the annuitant including provider expense loadings (i.e. commissions and administration fees). Explicit assumptions must be made about mortality risk, the annuitant's age, the interest rate used by the insurance company to discount expected benefit payments, and the cost structure of the insurance company.

Following Albrecht and Maurer (2002), we take the basic annuitant mortality table DAV 1994 R provided by the German Society of Actuaries for the specification of the demographic parameters. The table offers sex-specific mortality rates $\mathrm{q}_{\mathrm{x}}\left(\mathrm{q}_{\mathrm{y}}\right)$ for male and female. From these sex specific mortality rates we construct the mortality rates of a unisex table as a weighted average of $q_{x}$ and $\mathrm{q}_{\mathrm{y}}$. The interest rate (adjusted for inflation) used to discount expected annuity payments is set to an annual 1.5\%, consistent with the current yield of Euro-based inflation-linked bonds. Regarding the cost-structure of the insurance company, it is assumed that the total expense loading relative to the pure actuarial premium is $2.785 \%$. Given these assumptions, table Al shows the yearly real benefits a retiree with age 60,65 and 70 would receive per 100 EUR of premium.

Table A1. Immediate Annual Life-long Real Annuity Benefits per EUR 100 Single Premium: Total Expense Loadings 2.785\%; Discount Factor 1.5\%; DAV R 94 Mortality Tables

\begin{tabular}{|l|l|l|l|}
\hline Mortality Table & Male & Female & Unisex \\
\hline Retirement Age & \multicolumn{2}{|l|}{ Life Annuity $€$ p.a. } & 4.61 \\
\hline $\mathbf{6 0}$ & 4.95 & 4.32 & 5.37 \\
\hline $\mathbf{6 5}$ & 5.82 & 5.02 & 6.44 \\
\hline $\mathbf{7 0}$ & 7.03 & 5.99 & \\
\hline
\end{tabular}

Source: Authors' calculations. 


\section{Appendix B: Determining Expected Benefits, Expected Bequest and the Risk of a Consump- tion Shortfall for Phased Withdrawal Plans with given Benefit-to-Wealth Ratios}

Let $\omega_{\mathrm{t}}=B_{t} / V_{t}(t=0,1, \ldots$,$) be a predetermined sequence of benefit-to-wealth ratios 0 \leq \omega_{\mathrm{t}} \leq$ 1 , and define $c \omega_{t}=\prod_{i=0}^{t}\left(1-\omega_{i}\right)$. The retirement accounts assets (adjusted for inflation) used to fund the variable pension benefits $B_{t}$ are assumed to follow a geometric random walk with drift. This implies that the real $\log$ returns $I_{t}$ over the year are serially independent and identically normal distributed with given mean $\mu$ and volatility $\sigma$. Given an initial endowment $V_{0}$ at the beginning of the retirement phase, the market value of the retiree's account at the beginning of year $t(t=1,2, \ldots)$ just before the withdrawal $B_{t}$ for that year is made:

$$
V_{t}=\left(1-\omega_{t-1}\right) V_{t-1} \exp \left(I_{t}\right)=c \omega_{t-1} V_{0} \exp \left(\sum_{i=1}^{t} I_{t}\right) .
$$

$V_{t}$ is distributed log-normally, i.e. $\ln \left(V_{t}\right) \sim \mathrm{N}\left(m_{t}, v_{t}^{2}\right)$ follows a normal-distribution with mean $m_{t}=$ $\ln \left[c \omega_{t-1} V_{0}\right]+t \mu$ and variance $v_{t}^{2}=t \sigma^{2}$. Consequently, the benefit payments $B_{t}$ at the beginning of each period:

$$
B_{t}=\omega_{t} V_{t}=\omega_{t} c \omega_{t-1} V_{0} \exp \left(\sum_{i=1}^{t} I_{t}\right)
$$

are also log-normally distributed, i.e. $\ln \left(B_{t}\right) \sim \mathrm{N}\left(n_{t}, \nu_{t}^{2}\right)$ with parameters $n_{t}=\ln \left[\omega_{t} c \omega_{t-1} V_{0}\right]+t \mu$. With these formulas in hand, and additional assumptions about the expected return $\mu$ and volatility $\sigma$ of the retirement accounts assets, it is possible to compute for the variable phased withdrawal rules - i.e. fixed fraction, $1 / T$ and $1 / \mathrm{E}(T)$ - various risk and return measures of future benefits if the retiree is alive as well as the possible bequest in the case he dies.

The expected benefit payments $\mathrm{E}\left[B_{t}\right]$ in each period $t=0,1, \ldots$ are given by:

$$
\mathrm{E}\left[B_{t}\right]=\exp \left(n_{t}+{ }_{2}^{1} v_{t}^{2}\right)=\omega_{t} c \omega_{t-1} V_{0} \exp \left(t \mu+\frac{1}{2} t \sigma^{2}\right)
$$

and the expected bequest if the retiree dies in period $t=1,2, \ldots$ according to:

$$
\mathrm{E}\left[V_{t}\right]=\exp \left(m_{t}+{ }_{2}^{1} v_{t}^{2}\right)=c \omega_{t} V_{0} \exp \left(t \mu+\frac{1}{2} t \sigma^{2}\right)
$$

The shortfall probability that the benefits from a variable withdrawal plan is lower than a target annuity $z$ can be calculated as:

$$
\operatorname{SP}\left(B_{t}\right)=\Phi\left(q_{t}\right)
$$

where $\Phi$ is the cumulative density function of the Standard Normal Distribution at the point $q_{t}=\left(z-m_{t}\right) / \sigma \sqrt{t}$. Using the results given in Winkler et al., (1972) the shortfall expectation is:

$$
\operatorname{SE}\left(B_{t}\right)=z \cdot \Phi\left(q_{t}\right)-\mathrm{E}\left[B_{t}\right] \cdot \Phi\left(q_{t}-\sqrt{\sigma^{2} \cdot t}\right) .
$$

